\title{
Mifepristone for cervical ripening and induction of labour
}

\author{
Deepika. $\mathbf{N}^{1}$, Arun Kumar ${ }^{2, *}$ \\ ${ }^{1}$ Assistant Professor, Dept. of Obstetrics, MVJ medical college \& Research Hospital, Hoskote, Bangalore, Karnataka, ${ }^{2}$ Specialist, \\ Dept. of Gynaecology, Civil Hospital, Sunni, Shimla, Himachal Pradesh, India
}

*Corresponding Author:

Email: drakbang@gmail.com

\begin{abstract}
Objective: To study the efficacy of oral mifepristone in pre induction cervical ripening and induction of labour in term pregnancy.

Materials and Methods: This is a single blind randomised control trial. 200 women with term pregnancy and bishop score $<6$ were recruited and randomly allocated into two groups. Women who received tablet mifepristone $400 \mathrm{mg}$ were assigned to study group $(n=100)$ and who received placebo orally were assigned to control group $(n=100)$. At the end of 48 hours, change in the bishop was assessed and accordingly induction/ augmentation of labour was done. Analysis regarding safety and efficacy of the drug was done with regards to maternal and perinatal outcome

Results: Among 200 women, 100 received mifepristone and 100 received placebo. In mifepristone group, 75\% patients entered into labour within 48 hours of induction as compared to $48 \%$ in placebo group. The mean time interval between induction to start of labour pains was 28 hours $54 \mathrm{~min}$ in group A and 42 hours $18 \mathrm{~min}$ in group B. This difference was statistically significant. $(\mathrm{p}=0.000)$. In the study group $70 \%$ patients delivered within 48 hours of treatment as compared to $38 \%$ patients in control group. Mean induction delivery interval was 35 hours $38 \mathrm{~min}$ in study group and 49 hours 52 min in control group (p=0.000). There were fewer caesareans in the mifepristone treated group (10\%) than placebo group (20\%) particularly for failed induction $(2$ versus 6) and non progress of labour (2 versus 5). There was no statistically significant different in perinatal outcome between two groups.

Conclusion: Mifepristone has modest affect on cervical repining when given 48 hour prior to labour induction and appears to reduce need for further induction compared to placebo. Mifepristone is a simple and effective method of inducing labour in women with term pregnancy and unripe cervix. The use of Mifepristone provides an interesting new alternative to classic uterotonic agents when induction of labour is necessary.
\end{abstract}

Keywords: Mifepristone, Induction of labour, Misoprostol, Caesarean section, Bishop score.

\section{Introduction}

In an ideal world all pregnancies would go to term and labour would begin spontaneously. The progress of Medicine in general and of Obstetrics has allowed the termination of pregnancy at term or close to term for high risk pregnancies with maternal or foetal indication. Induction of labour is defined as an intervention designed to artificially initiate the uterine contractions leading to progressive dilation and effacement of cervix and birth of the baby.

The state of cervix is a major contributor for successful labour. When delivery is necessary and ripening has not had time to occur this natural process has to be accelerated. ${ }^{1}$ Labour induction in unfavourable cervix is a difficult and lengthy procedure, extenuating for both mother and obstetrician. So when labour induction is performed favourable cervix is fundamental to a good outcome. ${ }^{2}$ The status of cervix can be assessed by Bishop pelvic scoring system. Bishop score of less than 6 usually requires cervical ripening agent. ${ }^{3}$

Membrane sweeping and amniotomy for those females keen to avoid as much intervention as possible has been shown to result in established labour. ${ }^{4}$ There is widely held view that the manipulation of the cervix and vagina during the amniotomy provokes release of oxytocin from the posterior pituitary via the Ferguson reflex and this is followed a few minutes later by release of prostaglandins into the uterine vein, encouraging uterine contractility. ${ }^{5}$

Among mechanical methods balloon catheters, hygroscopic dilators derived from seaweed (Laminaria japonicum) and synthetic osmotic dilators (Dilapan, Lamicel) have shown to trigger release of endogenous prostaglandins or extract water from cervical tissue and cause cervix to expand. ${ }^{6}$ Trans cervical Foley 's catheter and extra amniotic saline infusion have been successfully used for cervical ripening and labour induction. ${ }^{7}$

During the past 15 years the introduction of PGE1 (misoptrostol), a methyl analogue has been the major focus of attention for labour induction as it is cheaper and easy to store because of thermo stability. Currently only prostaglandin E2 (PGE2) is licensed for use for labour induction in case of viable pregnancies. ${ }^{1}$

Mifepristone (RU-486), the progesterone receptor blocker has a dramatic effect upon reducing induction to abortion intervals during the second trimester therapeutic abortions. So it was hoped that a similar effect might be seen for labour induction at term. ${ }^{8}$ As it is a 19 nor - steroid which has greater affinity for progesterone receptors than does progesterone itself, it blocks the action of progesterone at the cellular level. It 
antagonizes progesterone and thus increases sensitivity of the uterus to prostaglandins and initiates the labour. ${ }^{9}$

Mifepristone has been recently used in cases of post-term pregnancies in comparison with a group receiving placebo. It does reduce the need of other drugs to induce labour. When compared to placebo there is evidence that risk for C-section is lower for women treated with Mifepristone. ${ }^{10}$

It probably is a new field for future research on cervical ripening and labour induction in viable pregnancies. But more research is needed to establish the optimal application, safety and efficacy of Mifepristone as an agent for cervical ripening and labour induction.

\section{Materials and Methods}

The study has been carried out in the Department of Obstetrics and Gynaecology, Kamla Nehru State Hospital for Mother and Child, Indira Gandhi Medical College, Shimla for a period of one year w.e.f. $1^{\text {st }}$ April 2012 to $31^{\text {st }}$ March 2013 on 200 pregnant females scheduled for planned delivery for various indications. Subjects were divided into 2 groups with 100 each. Group A included females who received tablet Mifepristone 400mg and Group B females received placebo in form of vitamin C. External appearance of the placebo was similar to that of Mifepristone tablet.

\section{Inclusion criteria:}

Singleton pregnancy with

i. cephalic presentation

ii. term pregnancy

iii. maternal or foetal indications for labour induction

iv. women in whom labour induction could be deferred for 48 hours

v. unfavourable cervix with Bishop's score $<6$

\section{Exclusion criteria:}

i. Non vertex presentation

ii. >1 previous caesarean section

iii. Multiple pregnancy

iv. Parity 5 or more

v. Diabetes Mellitus

vi. Contraindication to vaginal delivery

vii. Renal failure, hepatic disorder, adrenal insufficiency

viii. Women on aspirin or NSAIDS for last 15 days

ix. Women on anticoagulant therapy or corticosteroids

$\mathrm{x}$. Blood clotting disorders

xi. Known hypersensitivity to prostaglandins or Mifepristone

\section{Preliminary procedure}

In all women under study, detailed history, general physical examination, systemic examination and obstetrical examination including per vaginum was done and all investigations as in attached proforma were carried out. Informed written consent was taken.

\section{Drugs used in study}

1. Mifepristone tablet $400 \mathrm{mg}$

2. Vitamin C tablet

\section{Method of study}

Total number of 200 females planned for induction with Bishop's score of less than 6 were selected for the study. Hundred of these women were given tablet Mifepristone 400mg orally (Group A). Hundred consecutive women admitted for the induction of labour comparable to Group A received placebo in form of vitamin C (Group B). Before the medication was given, Bishop's score was assigned by vaginal examination. Number of women going in spontaneous labour within 48 hours of administration of the drug was noted. If the labour did not start within 48 hours, vaginal examination was repeated and Bishop's score was calculated. If Bishop's score was $\geq 6$, amniotomy was done and oxytocin was started. If Bishop's score still remained unfavourable $(<6)$ then the female was induced with intracervical prostaglandinE2 gel $(0.5 \mathrm{mg})$. Women with previous caesarean section were induced with Foley's catheter. Subjects were assessed after eight hours and second dose of prostaglandin E2 was instilled if Bishop's score did not improve. Examination was repeated again after 6 hours of second dose of PGE2 gel and if Bishop's score still remained unfavourable, caesarean section was performed for failed induction. If at any stage Bishop's score was 6 or more amniotomy was done and oxytocin infusion was started.

Active stage of labour was monitored partographically. Mode of delivery was noted down. Apgar score was recorded.

Efficacy of the drug was assessed by the number of women who went into spontaneous labour within 48 hours of Mifepristone administration or by Bishop's score of 6 or more at 48 hours.

The statistical difference between two groups was evaluated by using student $t$ test and Chi square test. The $p$ value of $<0.05$ was considered as statistically significant.

\section{Results}

Out of 100 study group women (Total $n=200$ ), maximum number of patients were between 25-29 years in both groups i.e.63\% in group A and 65\% in group B. The mean age was 25.54 years in group A and 25.75 in group B. Most of the patients who received labour induction were nulliparous i.e 58\% patients in group A and $52 \%$ patients in group $\mathrm{B}(\mathrm{p}=0.102)$. The mean gestational age at induction was 39.9 weeks in group A and 40.07 weeks in group $B(p=0.561)$. 
Table 1: Characteristics of study and control group

\begin{tabular}{|l|c|c|c|}
\hline Characteristic & $\begin{array}{c}\text { Group-A } \\
\text { (Study Group) } \\
\text { N=100 }\end{array}$ & $\begin{array}{c}\text { Group -B } \\
\text { (Control Group) } \\
\text { N=100 }\end{array}$ & P value \\
\hline Maternal age in yrs & 25.54 years & 25.75 years & 0.572 \\
\hline Gestational age & 39.9 weeks & 40.07 weeks & 0.567 \\
\hline Parity & & & 0.102 \\
i. Nulliparous & 58 & 52 & \\
ii. Para 1 & 22 & 16 & \\
iii. Para 2 & 18 & 24 & \\
iv. Para 3 & 2 & 8 & \\
\hline
\end{tabular}

The median Bishop score in group A and group B was 3

Table 2: Bishop Score Before Induction

\begin{tabular}{|c|c|c|}
\hline Bishop Score & $\begin{array}{c}\text { Group A } \\
\text { (Study Group) } \\
\mathbf{N = 1 0 0}\end{array}$ & $\begin{array}{c}\text { Group B } \\
\text { (Control Group) } \\
\mathbf{N = 1 0 0}\end{array}$ \\
\hline 2 & 12 & 10 \\
\hline 3 & 33 & 36 \\
\hline 4 & 35 & 29 \\
\hline 5 & 20 & 25 \\
\hline
\end{tabular}

The mean time interval between induction to start of labour pains was 28 hours 54 min in group A and 42 hours $18 \mathrm{~min}$ in group B. This difference was highly significant statistically. $(\mathrm{p}=0.000)$

Table 3: Time interval between induction to onset of labour pains

\begin{tabular}{|l|c|c|c|}
\hline \multicolumn{1}{|c|}{ Time(hrs) } & $\begin{array}{c}\text { Group A } \\
\text { (Study Group) } \\
\text { N=100 }\end{array}$ & $\begin{array}{c}\text { Group B } \\
\text { (Control Group) } \\
\text { N=100 }\end{array}$ & P value \\
\hline $0-12$ & 27 & 7 & 0.000 \\
\hline $12-24$ & 20 & 14 & \\
\hline $24-36$ & 17 & 14 & \\
\hline $36-48$ & 11 & 13 & \\
\hline$>48$ & 25 & 52 & \\
\hline
\end{tabular}

During the first 48 hours following treatment, 75 women treated with Mifepristone and 48 treated with placebo went into labour $(\mathrm{p}=0.048)$. Bishop score of less than 6 was found in 20 women in Mifepristone group and 50 in placebo group which was highly significant statistically $(\mathrm{p}=0.000)$.

Table 4: Outcome at 48 hours after induction

\begin{tabular}{|c|c|c|c|}
\hline Outcome & $\begin{array}{c}\text { Group A } \\
\text { (Study Group) } \\
\text { N=100 }\end{array}$ & $\begin{array}{c}\text { Group B } \\
\text { (Control Group) } \\
\mathbf{N = 1 0 0}\end{array}$ & P value \\
\hline Spontaneous labour & 75 & 48 & 0.000 \\
\hline Bishop Score $\geq 6$ & 5 & 2 & \\
\hline Bishop Score $<6$ & 20 & 50 & \\
\hline
\end{tabular}

15 patients in group A and 42 patients in group B required Dinoprostone gel for further induction. This difference was highly significant $(\mathrm{p}=0.000)$.

Table 5: Mode of induction in patients with unfavourable Bishop Score at 48 hours.

\begin{tabular}{|l|c|c|c|}
\hline Mode of induction & $\begin{array}{c}\text { Group A } \\
\text { (Study Group) } \\
\text { N=20 }\end{array}$ & $\begin{array}{c}\text { Group B } \\
\text { (Control Group) } \\
\mathbf{N = 5 0}\end{array}$ & P value \\
\hline Dinoprostone gel & 15 & 42 & 0.000 \\
\hline Foley's Catheter & 5 & 8 & \\
\hline
\end{tabular}


The mean induction to delivery interval in group A was $35.38 \mathrm{hrs}$ and $49.52 \mathrm{hrs}$ in group B. Induction to delivery interval between the 2 groups was highly significant ( $\mathrm{p}=0.000)$.

Table 6: Time Interval between Induction To Delivery

\begin{tabular}{|c|c|c|c|}
\hline Time(hrs) & $\begin{array}{c}\text { Group A } \\
\text { (Study Group) } \\
\text { N=100 }\end{array}$ & $\begin{array}{c}\text { Group B } \\
\text { (Control Group) } \\
\text { N=100 }\end{array}$ & P value \\
\hline $0-12$ & 14 & 2 & 0.000 \\
\hline $12-24$ & 19 & 6 & \\
\hline $24-36$ & 24 & 14 & \\
\hline $36-48$ & 13 & 16 & \\
\hline$>48$ & 30 & 62 & \\
\hline
\end{tabular}

Eighty two patients in group A had normal vaginal delivery as compared to 71 in group B. Ten patients in group $A$ and 20 in group B had caesarean sections. The difference was statistically significant. $(p=0.001)$

Table 7: Mode of Delivery

\begin{tabular}{|l|c|c|c|}
\hline Mode of delivery & $\begin{array}{c}\text { Group-A } \\
\text { (Study } \\
\text { Group) } \\
\text { N=100 }\end{array}$ & $\begin{array}{c}\text { Group-B } \\
\text { (Control } \\
\text { Group) } \\
\text { N=100 }\end{array}$ & P value \\
\hline Normal Vaginal & 82 & 71 & 0.001 \\
delivery & 10 & 20 & 0.124 \\
\hline LSCS & 2 & 6 & \\
-Failed induction & 2 & 5 & \\
-Non progressof labour & 6 & 9 & \\
-Fetal distress & 8 & 9 & \\
\hline Instrumental delivery & 7 & 8 & \\
-Fetal distress & 1 & 1 & \\
-Prolonged 2 & & & \\
\hline
\end{tabular}

6 patients had nausea and vomiting, 2 had hyperthermia after mifepristone use.

8 patients in group A had meconium stained liqour as compared to 12 in group B. 2 patients in group A and 3 patients in group B had atonic $\mathrm{PPH}$. The difference was not statistically insignificant. $(\mathrm{p}=0.732)$.

The mean birth weight was $2.75 \mathrm{~kg}$ in study group and $2.74 \mathrm{~kg}$ in control group. The mean birth weight is comparable in both groups $(\mathrm{p}=0.910)$. Two babies in group A and 1 in group B had Apgar score $<7$ at 5 minute. These needed resuscitation. Neonatal hyperbilirubinemia was observed in 8 babies in group $\mathrm{A}$ and 7 in group B. Observations regarding neonatal outcome were comparable in both groups.

\section{Discussion}

Research continues to invent and modify doses of different drugs for induction of labour. Mifepristone has been used to induce labour or to allow pregnancy to be terminated. In the present study, we opted for $400 \mathrm{mg}$ mifepristone as a tablet and women will get the exact dose without fail.

The incidence of nulliparity was $58 \%$ in study group and $52 \%$ in control group in present study. The distribution of pregnancies and deliveries did not differ significantly between the two groups which was comparable to frydman et $\mathrm{al}^{11}$ and stenlund et al. ${ }^{12}$ In study by Mc Gill, $72 \%$ patients in each group were nulliparous. In all these studies most of the women who received labour induction were nulliparous.

The median Bishop Score at the start of induction was similar in both groups which was comparable to stenlund et $\mathrm{al}^{12}$ and Elliot et al. ${ }^{13}$ During the first 48 hours after the treatment was started $75 \%$ women who were given Mifepristone and $48 \%$ who were given placebo went into labour which was comparable to Elliot et al ${ }^{13}$ and Giacolone et al. ${ }^{14}$

In Frydman ${ }^{11}$ study, spontaneous onset of labour occurred in 31(54\%) patients in study group but only in 10(18\%) patients in placebo treated females. The number of patients with onset of labour pains within 48 hours of induction was less than the present study. As Mifepristone success is known to increase with gestation age in late pregnancy and especially after 40 weeks, the difference in gestation age at inclusion in our study and Frydman et al study could partly explain our positive result.

In our study statistically significant improvement was observed in mean time interval between induction to onset of labour pains which was $28 \mathrm{hrs} 54 \mathrm{~min}$ in study group and $42 \mathrm{hrs} 18 \mathrm{~min}$ in control group $(\mathrm{p}=0.000)$ which was comparable to Stenlund et al. ${ }^{12}$ 
Mean induction delivery time was 35 hours 38 min in study group and 49 hours $52 \mathrm{~min}$ in control group. It was significantly more in control group indicating that Mifepristone is an efficient inducing agent at term pregnancy $(\mathrm{p}=0.000)$ which is comparable to Stenlund ${ }^{12}$ and Wing et al. ${ }^{4,3}$

In our study caesareans were performed in $10 \%$ women in group A and $20 \%$ in group B. Elliot et al observed higher rate of caesarean section i.e. $36 \%$ and $26 \%$ in Mifepristone and control group respectively probably because the dose of Mifepristone used in their study was $200 \mathrm{mg}$ where as in our study it was $400 \mathrm{mg}$.

Women with unripe cervix treated with mifepristone more likely went into spontaneous labour than women of expectant management after 48 hours. Mifepristone in contrast to well established methods of labour induction, like usage of misoprostol or oxytocin or dinoprostone is not the direct inducer of uterine contractions. Main goal of mifepristone usage is preparation for natural start of labour or optimisation of next steps of induction process (to decrease induction delivery interval and to reduce dose of direct inductors of uterine contractions). ${ }^{15,16}$ Cervical ripening and shorter interval to delivery were related to decrease in frequency of meconium stained amniotic fluid.

Mifepristone is well tolerated in pregnant females. Indeed many women have used this medication at a dose of $600 \mathrm{mg}$, for first trimester abortion or late termination of pregnancy with an abnormal or dead fetus. In keeping with literature we observed no significant increase in adverse effects among females taking Mifepristone. ${ }^{11-14}$ Only minor side effects were observed in form of nausea and vomiting, headache, sweating and hyperthermia. Similar side effects were observed by Elliot et $\mathrm{al}^{13}$ and Lelaidier et al. ${ }^{18}$

Patients had only minor gastrointestinal side effects in form of nausea, vomiting, hyperthermia, headache and sweating. These were comparable in both groups. None of the patient in Mifepristone group had hypertonus or tachysysole which was comparable to Wing et al. ${ }^{15}$ Mean birth weight of the babies in present study is less than the other studies but it is in conformity to the average birth weight in India. ${ }^{6}$

\section{Conclusion}

Mifepristone is a simple and effective method of inducing labour in women with term pregnancy and unripe cervix. The use of Mifepristone provides an interesting new alternative to classic uterotonic agents when induction of labour is necessary. There were no significant difference in main maternal and neonatal outcomes between mifepristone use and placebo. The potential advantages of Mifepristone over prostaglandins or oxytocin requires further evaluation, mainly for situations in which these are contraindicated as in scarred uterus.

\section{References}

1. MacKenzie IZ. Induction of labour at the start of the new millennium. Reproduction 2006;131:989-98.

2. Fernanda Garanhani de Castro Surita, Jose Guilherme Cecatti, Fabiana Kruppa, Ricardo Porto Tedesco, Mary Angela Parpinelli. Cervical ripening methods for labour induction. Rev. Bras. Saude Matern. Infant, Recife 2004;4:125-33.

3. Tenore JL. Methods for cervical ripening and induction of labour. Am Fam Physician 2003;67:2123-8.

4. Swann RO. Induction of labour by stripping membranes. Obstet Gynecol 1958;11:74-8.

5. Turnbull AC \& Anderson ABM. Uterine function in human pregnancy and labour. Scientific Basis of Obstetrics and Gynecology, 1978;79-108.

6. Kramer J, O' Brien WF. Mechanical methods of cervical ripening. Clin Obstet Gynecol 1995;38:680-4.

7. Karjane NW, Brock EL, Walsh SW. Induction of labor using a foley balloon, with and without extra-amniotic saline infusion. Obstet Gynecol 2006;107:234-9.

8. Selinger M, MacKenzie IZ, Gillmer MDG, Phipps SL, Ferguson J. Progesterone inhibition in midtrimester termination of pregnancy: physiological and clinical effects. Br J Obstet Gynecol 1987;94:1218-22.

9. Hapangama Dharani, Neilson JP. Mifepristone for induction of labour. Cochrane Database of Systematic Reviews 2009, Issue 3. Art. No:CD002865. DOI: 10.1002/14651858.CD002865.pub2.

10. Neilson JP. Mifepristone for induction of labour. Cochrane review. The Cochrane Library 2004(1)2004 [Update software].

11. Frydman R, Lelaidier C, Baton C, Fernandez H, Vial M, Bourget $\mathrm{P}$. Labour induction in women at term with mifepristone (RU 486): A double blind randomized placebo controlled study. Obstet Gynecol 1992;80:972-5.

12. Stenlund PM, Bygdeman M, Ekman G. Induction of labour with Mifepristone- A randomized, double-blind study versus placebo. Acta Obstet Gynecol Scand 1999;78:793-8.

13. Elliott CL, Brennand JE, Calder AA. The effects of mifepristone on cervical ripening and labor induction in primigravidae. Obstet Gynecol 1998;92:804-9.

14. Giacolone PL, Targosz V, Laffargue F, Boog G, Faure JM. Cervical ripening with mifepristone before labour induction: A randomized study. Obstet Gynecol 1998;92:487-92.

15. Wing DA, Fassett MJ, Mishell DR. Mifepristone for preinduction cervical ripening beyond 41 weeks gestation: A randomized controlled trial. Obstet Gynecol 2000;96(October (4)):543-8.

16. Yelikar K, Deshpande S, Deshpande R, Lone D. Safety and efficacy of oral mifepristone in pre-induction cervical ripening and induction of labour in prolonged pregnancy. J Obstet Gynaecol India 2015;65 (July (4)):221-5.

17. Lelaidier C, Baton C, Benifla JL, Fernandez H, Bourget $\mathrm{PH}$, Frydman R. Mifepristone for labour induction after previous caesarean section. Br J Obstet Gynaecol 1994;101:501-3. 